\title{
Lepidoptera Britannica; sistens digestionem novam insectorum lepidopterorum quœ in Magnâ Britanniâ reperiuntur, larvarum pabulo, temporeque pascendi; expansione alarum; mensibusque volandi; synonymis atque locis observationibusque variis.
}

\section{A.H. Haworth}

To cite this article: A.H. Haworth (1828) Lepidoptera Britannica; sistens digestionem novam insectorum lepidopterorum quœ in Magnâ Britanniâ reperiuntur, larvarum pabulo, temporeque pascendi; expansione alarum; mensibusque volandi; synonymis atque locis observationibusque variis. , Philosophical Magazine Series 2, 3:17, 370-370, DOI: $10.1080 / 14786442808674667$

To link to this article: http://dx.doi.org/10.1080/14786442808674667

Published online: 10 Jul 2009.

Submit your article to this journal $๘$

Џll Article views: 2

Q View related articles $₫$

Citing articles: 1 View citing articles ๔ૉ 
scriptions, a principal object will be to render the work generally useful and interesting to the British naturalist.

The parts will follow each other with every degree of expedition consistent with the preservation of the style of publication in which the work has been commenced. Those preparatory arrangements which are inseparable from every undertaking of this nature have in some measure retarded the first part, but the publishers are enabled to engage, with every prospect of success, a regular continuation of the work : accordingly they announce the appearance of the second part early in July next, of the third, at the commencement of the ensuing year, and of the remaining parts at intervals of six months. According to this plan, the whole will be completed within three years from the commencement.

Lepidoptera Britannica; sistens Digestionem novam Insectorum Lepidopterorum que in Magnâ Britanniâ reperiuntur, larvarum pabulo, temporeque pascendi; expansione alarum; mensibusque volandi; synonymis atque locis observationibusque variis. Autore A. H. Haworth, Linn. Soc. Lond. Soc., \& c. \& c.

We congratulate the admirers of British Entomology on the long expected appearance of Part IV. of Mr. Haworth's Lepidoptera Britannica, which is at last completed.

This comprehensive and valuable work consists of 609 closely printed octavo pages, and 36 of Preface, and has been divided into four parts; to the first of which was appended above 200 similar pages, called Miscellanea Naturalia.

Complete new-wrought descriptions and synonymies of all the known British Lepidoptera are given throughout in Latin; together with occasional observations in English, respecting their peculiarities, size, food, times and places of appearance, \&c.

The First Part, which was published by the author in 1803, contains the Papilionida, Sphingide, and Bombycida. After this, the work languished for want of encouragement, till the beginning of 1809, when the Second Part was published. It contains the Hepiali, Lithosia, Falcaria, Noctuade, Phalcenadce, \&c.

The Third Part appeared in 1811. It contains the Pyralide, Tortricida, \&c. And the Fourth Part, which has just been published, completes the arduous and useful undertaking of its indefatigable author. It contains the Tinead $\&, \& c$. ; and concludes the work with a complete Index of all the genera and species of Lepidoptera described; about 1450 in number.

\section{Proceedings of Learned Societies.}

ROYAL SOCIETY.

Feb. 21 \& 28.- $\mathrm{R}$ EAD An account of the accident to the packetship the New York, from lightning. By $\mathrm{T}$. Stewart Traill, M.D. of Liverpool. Communicated by Henry Brougham, Esq. M.P. F.R.S. 